\title{
Characterization of a changing relationship between milk production and liveweight for dairy goats undergoing extended lactation
}

\author{
F. Douhard, ${ }^{*} \dagger \ddagger \S^{1}$ N. C. Friggens, ${ }^{\star} \ddagger$ J. Tessier, ${ }^{\star} \ddagger$ O. Martin, ${ }^{*} \ddagger$ M. Tichit, $† \S$ and D. Sauvant ${ }^{\star} \ddagger$ \\ *INRA, UMR 791 MoSAR, F-75005 Paris, France \\ †INRA, UMR 1048 SADAPT, F-75005 Paris, France \\ ¥AgroParisTech, UMR 791 MoSAR, F-75005 Paris, France \\ §AgroParisTech, UMR 1048 SADAPT, F-75005 Paris, France
}

\begin{abstract}
This study aimed to characterize the time-profile of extended lactation (EL) for dairy goats, and the relationships between milk production, liveweight, and intake that are associated with this profile. For this, 20 nonpregnant multiparous dairy goats were monitored daily for about $90 \mathrm{~d}$ from the onset of EL [i.e., when an increase in milk yield (MY) was observed]. These 20 individual profiles were pooled to create a group average profile at the onset of EL for the purpose of parameterizing a simple compartmental model. Moreover, 9 of the 20 EL goats were kept to compare their 24-mo profiles of body weight and milk production with those observed during 2 successive normal lactations (NL). Despite being kept in the same environment and on the same feed, a clear change from decreasing to increasing MY was identified (time of change, $\mathrm{T}_{\text {change}}$ ) for all of the 20 EL goats around $330 \mathrm{~d}$ in milk. During the whole 24-mo period, EL goats produced as much milk as NL goats but this total milk production was unequally split before (56\%) and after (44\%) $\mathrm{T}_{\text {change. }}$ In terms of body weight, the most striking difference between EL and NL goats was the rapid and very high increase $(+9.3 \mathrm{~kg}$ with an average daily gain of 60.4 $\mathrm{g} / \mathrm{d}$ ) that was observed concurrently with the increase in MY. Model parameterization with the group average profile does not support that the rise in MY drives the increase in resource acquisition as is generally assumed at the onset of an NL. Rather, it demonstrates that the transfer of energy from feed to milk is delayed at the onset of EL. Moreover, assessing the model ability to fit the range of individual profiles showed that the performances over the first $90 \mathrm{~d}$ of EL are largely predetermined by the animal state at $\mathrm{T}_{\text {change }}$. The analysis of individual variability in EL efficiency showed that it depends both on an increase in resource acquisition and on the potential of goats to partition energy from the
\end{abstract}

Received November 13, 2012

Accepted June 3, 2013.

${ }^{1}$ Corresponding author: frederic.douhard@agroparistech.fr diet toward milk production instead of to body tissue gain. Finally, predicting the suitability for EL requires the consideration of more than just milk production for $300 \mathrm{~d}$ in milk.

Key words: dairy goat, extended lactation, modeling

\section{INTRODUCTION}

Extending the lactation of dairy females beyond 300 $\mathrm{d}$ is increasingly considered in the management strategies of cow and goat systems. The practical implications at the herd level have been explored (Rotz et al., 2005; Butler et al., 2010). However, these approaches are often confronted with a multiplicity of factors that potentially affect the efficiency of an extended lactation (EL) in a particular situation. This is especially the case for pasture-fed dairy cows where complex effects on production have been put forward as a result of different combinations of season, diet, and breed (Kolver et al., 2007; Grainger et al., 2009; Butler et al., 2010). These findings have stimulated interest in finding generic characteristics of EL that could be used across different nutritional contexts in dairy systems (Dematawewa et al., 2007; Steri et al., 2012). Despite qualitative similarities between the standard 300-d lactation of dairy cows and goats, some evidence exists that goats represent a particular case of EL. In the dairy cow, it is frequently reported that, even under nonlimiting nutritional conditions, milk yield (MY) continuously decreases after the normal 300-d period (Grainger et al., 2009). Very few reports exist describing EL in goats but in all of them, it seems that the onset of EL could be defined by an increase in MY (Chastin et al., 2001; Salama et al., 2005). In these 2-yr studies, EL did not lead to significant loss in MY compared with 2 lactations of $300 \mathrm{~d}$ with a 12-mo kidding interval. Moreover, it has been observed that well-fed dairy goats can extend their lactation to last from 2 to $4 \mathrm{yr}$ by increasing seasonally their milk secretion although an overarching trend existed for MY to decrease (Linzell, 1973). In this latter study, the seasonal fluctuations in MY throughout the lactation suggested that mammary 
function is not only affected by nutrition but that an underlying, innate, biological mechanism is involved beyond $300 \mathrm{~d}$ of lactation. This raises the question, as yet unexplored, of which animal factors influence this onset of EL. Together with the description of Salama et al. (2005), these results indicate the need for better characterization of EL profiles in the dairy goat, not just in terms of MY but also in terms of being able to model the performance parameters linked to nutrient partitioning. Accordingly, the present study aimed to characterize the time profile of EL for dairy goats, and the relationships between milk production, liveweight, and intake that are associated with this profile. Particular focus was given to the period when lactation is normally initiated, which is usually a critical period in dairy goats. A second aim was to model these changes so as to shed light on the animal factors influencing their shape.

\section{MATERIALS AND METHODS}

\section{Animals and Housing}

Twenty multiparous dairy goats (6 Saanen and 14 Alpine) were selected from the experimental herd of Grignon (France). After kidding in January 2009, these goats were not rebred 7 mo later as would usually be the case for goats with a 12-mo kidding interval in a normal lactation (NL). The 2-mo dry period was omitted for the goats in EL, which continued to be milked twice per day. This group was monitored in individual pens from December 21, 2010, to March 7, 2011, to characterize performance at the onset of EL (from about mo 11 to 14 of lactation). Beyond March 2011, 9 of the 20 goats were kept to compare 24-mo EL profiles (the 24-mo kidding interval, including 22 mo of lactation) with NL profiles that were selected a posteriori on the basis of similar BW and MY from 0 to 300 DIM. During their EL, goats were fed the same TMR diet as the other goats from the herd. The TMR consisted of grass hay $(250 \mathrm{~g} / \mathrm{kg}$ of DM), alfalfa $(240 \mathrm{~g} /$ $\mathrm{kg}$ of DM), sugar beet pulp (300 g/ $\mathrm{kg}$ of DM), brewer's grain $(50 \mathrm{~g} / \mathrm{kg}$ of DM), and concentrate blend $(160 \mathrm{~g} /$ $\mathrm{kg}$ of DM). The concentrate blend consisted of $25 \%$ wheat, $25 \%$ barley, $30 \%$ maize, $15 \%$ soybean meal, $3 \%$ molasses, and $2 \%$ mineral premix composed of $18 \% \mathrm{P}$, $14 \% \mathrm{Ca}$, and $6 \% \mathrm{Mg}$. Energy and protein values of the diet were calculated according to the Institut National de la Recherche Agronomique (INRA) tables (Baumont et al., 2007). True protein digested in the small intestine when fermentable $\mathrm{N}$ is limiting (PDIN) was $84.4 \mathrm{~g} / \mathrm{kg}$ of DM and true protein digested in the small intestine when fermentable energy is limiting (PDIE) was $83 \mathrm{~g} / \mathrm{kg}$ of DM. The net energy content of the diet
$\left(\mathbf{E}_{\text {diet }}\right)$ was $6.12 \mathrm{MJ} / \mathrm{kg}$ of DM [the INRA system uses a single energy unit for all physiological functions (i.e., the same efficiency is assumed for the conversion of $\mathrm{ME}$ to net energy)]. The quantities offered were adjusted weekly to achieve $10 \%$ refusals.

\section{Biometric Approach for Characterizing EL with the 24-mo Profiles}

Measurements. The profiles of performances of EL and NL were characterized with the data from routine herd monitoring. This was done weekly and included for each goat the average daily MY and a BW measure. Milk composition (fat and protein) and SCC were recorded monthly and are also reported in this study.

Performance-Matching Procedure. To get comparable profiles between EL and NL, the MY and BW curves before the onset of EL (i.e., from conception to wk 30 of lactation) were visually examined. For each EL, the NL candidate whose curves best matched was retained to form a pair. As far as possible, the 9 pairs were formed using NL data from 2010 and 2011. However, due to the requirements for the matching procedure, some NL profiles were chosen among data recorded from previous years.

Time Alignment of EL and the Second Lactation of NL. Visual inspection of the EL curves showed an increase in MY at about 330 DIM that could correspond to a physiological change. To detect more precisely when this change occurred for the different goats, a third-degree polynomial of MY on DIM was fitted for each EL animal in the period 300 to 390 DIM. The time of change ( $\left.\mathbf{T}_{\text {change }}\right)$ was defined as occurring when the estimated MY was at a minimum in the considered period (i.e., when the first derivative equaled zero).

For comparison with NL, each of the 24-mo EL profiles was split at $T_{\text {change }}$. The second part of EL profiles describing the performances from $\mathrm{T}_{\text {change }}$ to drying-off was then time aligned and compared with the second lactation of NL.

Statistical Analyses. Data were analyzed with a mixed model that contained the fixed effects of week of lactation (month of lactation for milk composition and SCC), the interaction between week of lactation and the treatment (NL or EL), the random effect of the pair (1 to 9), and the residual error. Analysis was performed with the lmer function from the lme4 package in the $\mathrm{R}$ environment (version 2.15.1; R Development Core Team, 2012).

\section{Study of the Onset of EL}

Measurements. For the 20 EL goats, MY, BW and DMI were recorded daily for $11 \mathrm{wk}$, starting from De- 
cember 21, 2010. During this period, goats were kept in $2 \times 1-\mathrm{m}$ individual pens to monitor DMI. Dry matter intake was calculated from the difference between the quantity offered and the refusals that were removed and measured every day at $1400 \mathrm{~h}$. Milk composition (fat and protein contents) was recorded every $3 \mathrm{~d}$. Energy balance (EB) was calculated according to the formula published by Sauvant et al. (2007). Details of the calculation are reported in the Appendix. The onset of each of the 20 EL was considered as a 90-d period starting at $\mathrm{T}_{\text {change }}$ (detected as before). On average, $\mathrm{T}_{\text {change }}$ occurred $11.5 \mathrm{~d}(\mathrm{SD}=10.3)$ before the start of the daily monitoring procedure. To compensate for the lack of data during the first days after $\mathrm{T}_{\text {change }}, \mathrm{BW}$ and MY records were partially completed with those from the weekly routine monitoring. The individual profiles obtained at the onset of EL were pooled to create a group average profile for the purpose of parameterizing a simple compartmental model. The model was built using ModelMaker software (version 3; Cherwell Scientific Ltd., Oxford, UK) to fit simultaneously the evolution of DMI, MY, milk composition, and BW at the onset of EL. The model parameters were also estimated using ModelMaker software. For clarity, the model rationale and its main equations are described together with the modeling results. Further details about the model equations are presented in the Appendix.

Statistical Analyses. The root mean square error (RMSE) was used to evaluate the quality of the model to fit the observed data. Using the group average profile, for each variable, RMSE was defined as follows:

$$
\operatorname{RMSE}=\sqrt{\frac{\sum_{\mathrm{i}=1}^{\mathrm{N}}\left(\mathrm{O}_{\mathrm{i}}-\mathrm{P}_{\mathrm{i}}\right)^{2}}{\mathrm{~N}}},
$$

where $\mathrm{O}_{\mathrm{i}}$ is the ith observed value, $\mathrm{P}_{\mathrm{i}}$ is the ith predicted value, and $\mathrm{N}$ is the total number of observations. A coefficient of determination (CD) was also calculated to quantify the ability of the model to explain the observed variability in the data.

To assess the model ability to fit the range of individual profiles $(\mathrm{n}=20)$ the model was run with the initial parameters $\left(\mathrm{DMI}_{0}, \mathrm{MY}_{0}, \mathrm{Fat}_{0}\right.$, Protein $_{0}$, and $\mathrm{BW}_{0}$ ) adjusted to each individual but keeping the other parameters fixed to group average profile values (Appendix; Table 1). The individual adjustments were evaluated globally with a CD quantifying the proportion of the intraindividual variability for each variable $\left(\mathbf{C D}_{\mathrm{RES}}\right) ; \mathrm{CD}_{\mathrm{RES}}$ was defined as follows:

$$
\mathrm{CD}_{\mathrm{RES}}=1-\frac{\sum_{\mathrm{k}=1}^{\mathrm{n}} \sum_{\mathrm{j}=1}^{\mathrm{n}_{\mathrm{k}}}\left(\mathrm{O}_{\mathrm{j}, \mathrm{k}}-\mathrm{P}_{\mathrm{j}, \mathrm{k}}\right)^{2}}{\mathrm{RSS}},
$$

with RSS $=\sum_{k=1}^{n} \sum_{j=1}^{n_{k}}\left(O_{j, k}-\bar{O}_{k}\right)^{2}$, where $O_{j, k}$ and $P_{j, k}$ are respectively the jth observation and prediction for the $\mathrm{kth}$ individual ( $\mathrm{n}=20$ individuals) and RSS is the residual sum of squares calculated with the mean of the $n_{k}$ observed data from the kth individual $\left(\overline{\mathrm{O}}_{\mathrm{k}}\right)$.

The relations between model parameters and goat performances during EL were explored with principal components (PC) analysis. The similarities between individuals were investigated with hierarchical clustering on PC using the Ward criterion of information. All the exploratory data analysis was performed with $\mathrm{R}$ and the FactoMineR package (version 1.19, 2012).

\section{RESULTS}

Despite being kept in the same environment and on the same feed, a clear change from decreasing to increasing MY ( $\mathrm{T}_{\text {change }}$ ) was identified for all of the 20 EL goats around 330 DIM (mean \pm SD $=333 \pm 18.3$ DIM). This occurred between November 20, 2010, and December 24, 2010, without any obvious relation with the date of previous kidding.

\section{Comparison of EL with the 24-mo Profile of 2 Successive $N L$}

The comparisons of average daily $\mathrm{MY}$ and $\mathrm{BW}$ are presented in Figure 1. The first-lactation period in EL goats (labeled $\mathbf{n}-\mathbf{1}$ ) was similar to the equivalent lactation of NL and was thus considered as a basis for further comparison between EL and NL. During this period, significant differences $(P<0.05)$ in MY and BW occurred from wk 37 onward, at which time NL goats were $7 \mathrm{wk}$ pregnant. The average BW of EL goats showed almost no increase from wk 37 to $\mathrm{T}_{\text {change, }}$ even though no pregnancy-associated increase in energy requirements occurred during this time and the requirements for milk were decreasing, as indicated by the decrease in MY.

From the second period (labeled $\mathbf{n}$ ) beginning at $\mathrm{T}_{\text {change, }}$ the average MY of EL goats increased for about 23 wk and peaked at $3.7 \mathrm{~kg} / \mathrm{d}$; that is about only $85 \%$ of the peak observed in period $n-1$ (Figure 1A). A substantial increase in BW was also observed at the same time (Figure 1B). The EL profiles in the first 23 wk of period $n$ are markedly different from NL because MY increased much more gradually after $T_{\text {change }}$ than after kidding, but for a period about 3 times longer than NL (peak at wk 10 of lactation). Moreover, as seen for NL goats, a phase of increasing MY is normally associated with body fat mobilization and, consequently, with BW loss, whereas EL goats exhibited high ADG 
A

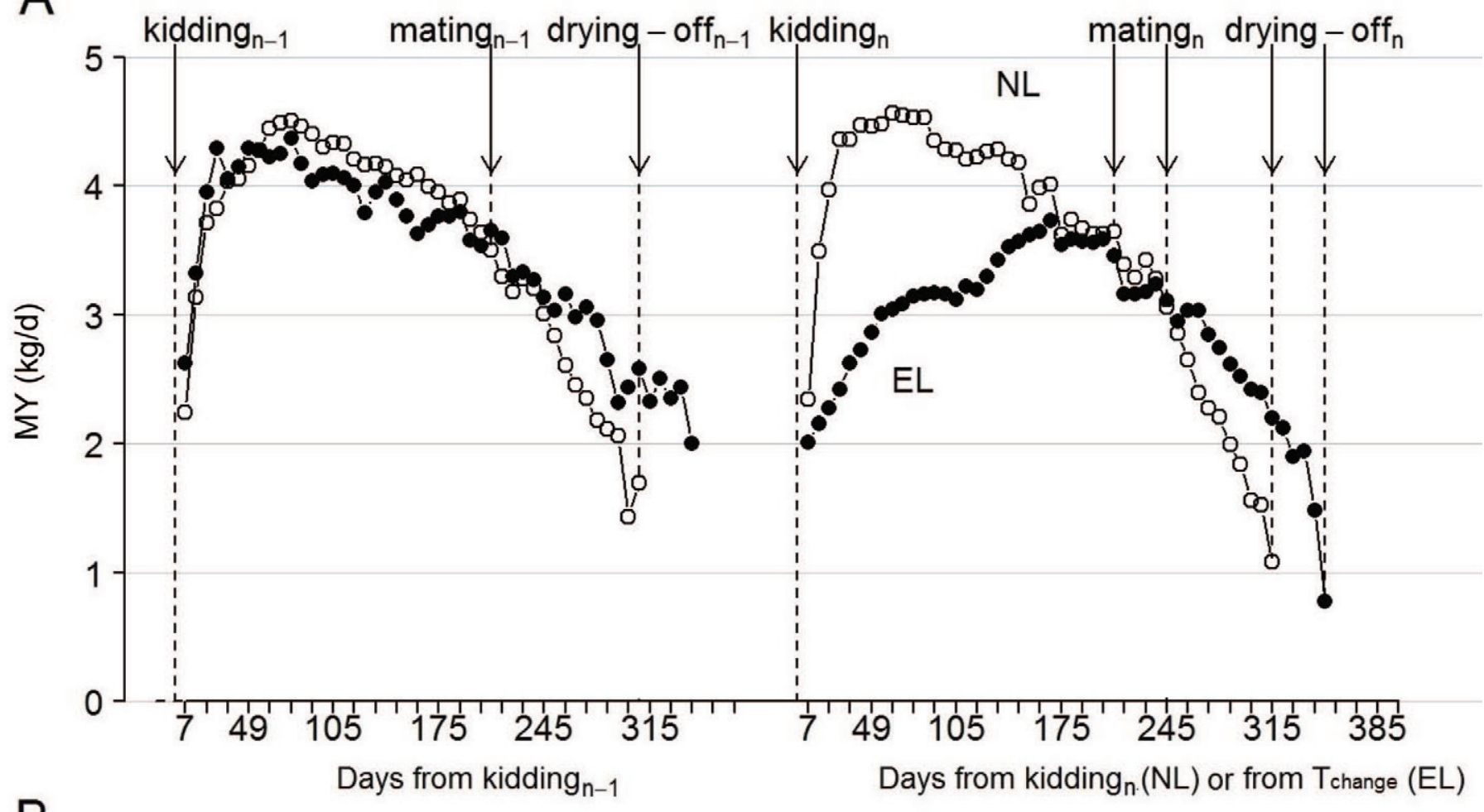

B

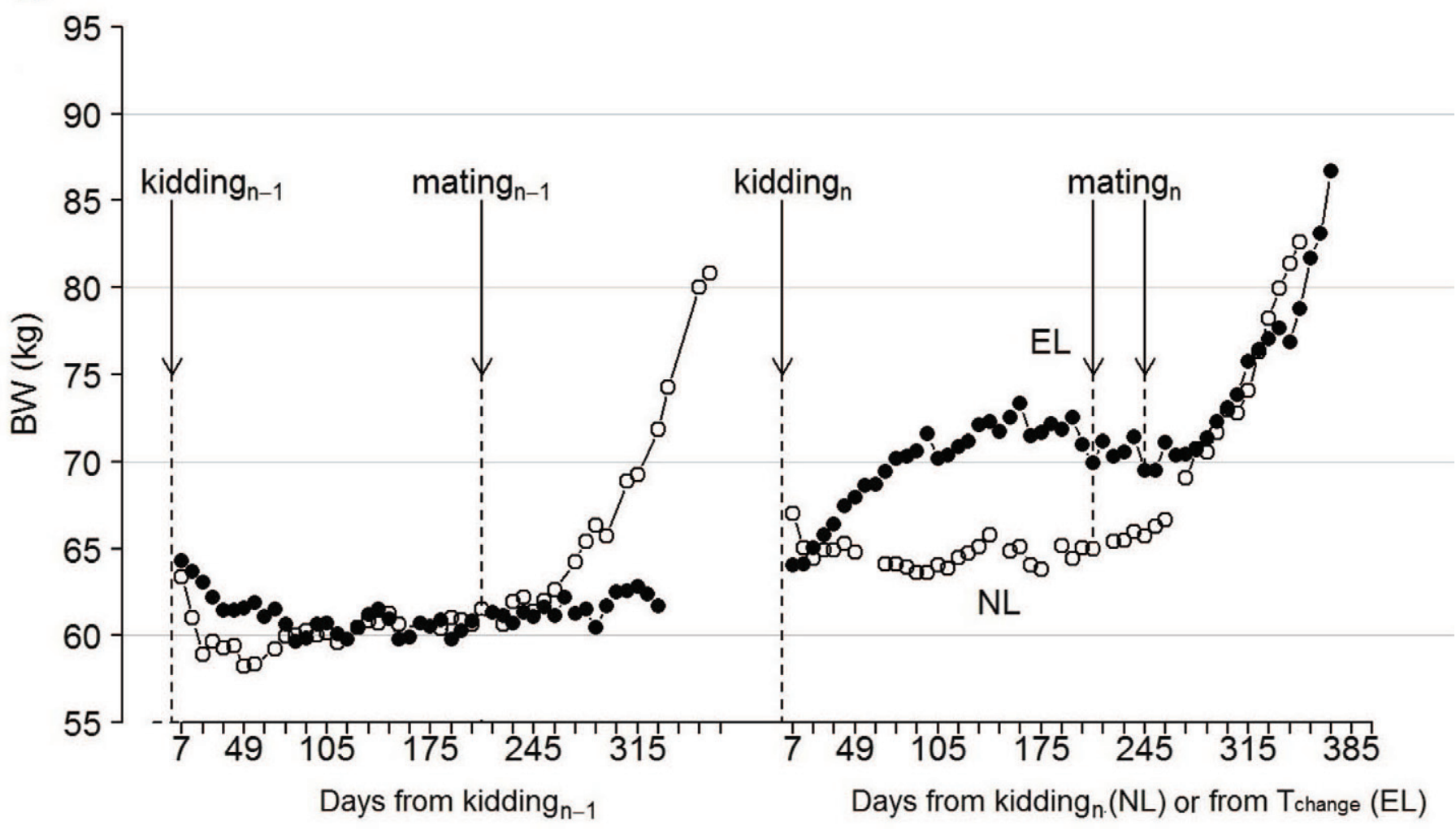

Figure 1. (A) The average milk yield (MY) and (B) BW of dairy goats in extended lactations (EL; $\bullet$; n = 9) and normal lactations (NL; $O ; n=9)$. Period $n-1$ denotes the first lactation in the study for NL goats and the equivalent period for EL goats. Period $n$ denotes the second lactation for NL goats and the time-aligned EL of EL goats. The time point used to split the extended lactation into periods $\mathrm{n}-1$ and $\mathrm{n}$ ( $\mathrm{T}_{\text {change }}$ ) was the point at which MY started to rise again (see Materials and Methods for further explanation). 
(average $=60.4 \pm 9.4 \mathrm{~g} / \mathrm{d}$ ) during the first $23 \mathrm{wk}$ of the period n. After these $23 \mathrm{wk}$, MY decreased until drying-off $_{\mathrm{n}}$ and $\mathrm{BW}$ remained globally steady (slightly decreasing) until wk 38. Mating occurred at wk 35 and BW increased about 6 wk after due to pregnancy, similarly to NL. The average BW by the end of pregnancy was equivalent for EL and NL. Thus, from wk 23 of period n, EL goats recovered BW and MY dynamics patterns similar to those of NL goats. During the whole 24-mo period, EL goats produced as much milk $(2,192$ $\pm 68 \mathrm{~kg}$ /goat $)$ as NL goats $(2,193 \pm 85 \mathrm{~kg} /$ goat $)$ but contrarily to NL production, this EL milk production was unequally split between period $n-1(56 \%)$ and $n$ (44\%). No significant differences were detected in milk fat and protein contents and in SCC between EL and NL goats (Figure 2).

Given that the substantial differences between EL and NL profiles occurred at the same time, under the same feeding conditions, and in the same environment, it seems clear that another driver of nutrient partition and milk production exists, other than feed quality and DIM. As a means to explore this, we adopted a modeling approach to the EL data.

\section{Modeling the Group Average Profile at the Onset of EL}

The purpose of this modeling work was to characterize the linkage between intake, milk production, and BW and in particular the time lags between their dynamics, as this provides information on which of these is driving the others. For this reason, the model does not attempt to describe specific physiological mechanisms.

To represent an overall dynamic at the onset of EL, the group average profile calculated from the 20
EL-onset profiles was used to parameterize the initial model. The profiles of 6 characterizing variables are presented in Figure 3A (DMI and MY), 3B (BW and $\mathrm{EB}$ ), and $3 \mathrm{C}$ (milk fat and protein contents). During the $90 \mathrm{~d}$ of the onset profile, DMI as well as MY seemed to increase according to a nonlinear trend over the $90 \mathrm{~d}$ (Figure 3A), although DMI appeared to increase faster to its asymptotic value than MY. Body weight seemed to increase linearly from about 65 to $72 \mathrm{~kg}$ (Figure $3 \mathrm{~B}$ ), with an ADG of about $80 \mathrm{~g} / \mathrm{d}$. However, relatively few measures of BW were available for the first 2 wk, whereas some increase in ADG could occur at this moment. The increase in BW was consistent with the positive values of the calculated EB (mean value of $+3.03 \pm 0.13 \mathrm{MJ} / \mathrm{d}$ ). Mean milk fat and protein content decreased in a similar fashion, although much more individual variation was observed for fat.

Figure 4 presents the diagram of the model used together with the main equations (further details are provided in the Appendix). Parameter definitions are presented in Table 1. Model development was based on the approach proposed by Sauvant (1994), and previous applications of this approach (Puillet et al., 2008; Desnoyers et al., 2009). The basic principle consisted in building the simplest possible dynamic compartmental structure that allows time lags between driving factors to be quantified. In our case, this structure was built on the hypothesis of a global delay in the transfer of energy from feed to milk during the whole onset period of EL. The underlying dynamic was based on 2 successive first-order reactions: $\mathrm{A} \rightarrow \mathrm{B} \rightarrow \mathrm{C}$, where $\mathrm{A}, \mathrm{B}$, and $\mathrm{C}$ are relative quantities of these linked driving factors that control the variables DMI, MY, Fat, and Protein. The change with time of $\mathrm{A}, \mathrm{B}$, and $\mathrm{C}$ is presented in Figure 5. The fractional outflow rates $\left(\mathbf{k}_{\mathrm{AB}}\right.$ and $\left.\mathbf{k}_{\mathrm{BC}}\right)$
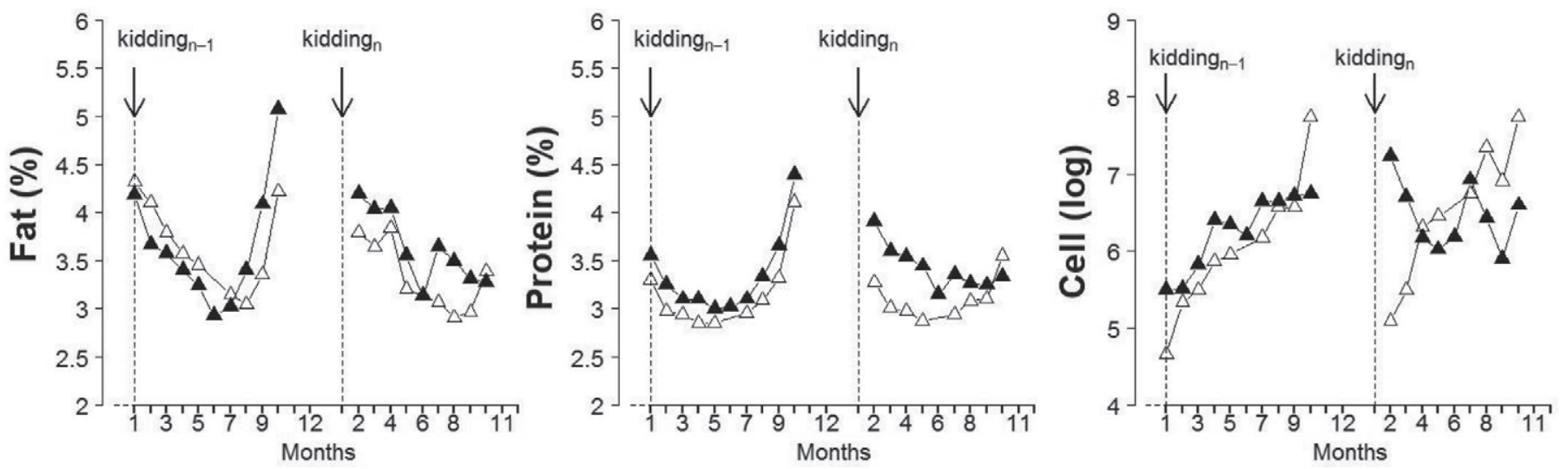

Figure 2. Average milk fat, protein, and SCC for extended lactation (EL; $\mathbf{\Delta} ; \mathrm{n}=9)$ and normal lactation $(\mathrm{NL} ; \Delta ; \mathrm{n}=9)$. Period $\mathrm{n}-1$ denotes the first lactation in the study for NL goats and the equivalent period for EL goats. Period n denotes the second lactation for NL goats and the time-aligned EL of EL goats. The time point used to split the extended lactation into periods $\mathrm{n}-1$ and $\mathrm{n}$ ( $\left.\mathrm{T}_{\text {change }}\right)$ was the point at which milk yield started to rise again (see Material and Methods for further explanation). 
Table 1. Definition of the parameters used in the model to predict a group average time profile of performances at the onset of extended lactation in dairy goats ${ }^{1}$

\begin{tabular}{|c|c|c|c|}
\hline $\begin{array}{l}\text { Parameter } \\
\text { name }\end{array}$ & Units & Description $^{2}$ & $\begin{array}{l}\text { Value adjusted to the } \\
\text { average profile }(\mathrm{n}=20)\end{array}$ \\
\hline $\mathrm{k}_{\mathrm{AB}}$ & $1 / \mathrm{d}$ & Fractional outflow rate from A to B & 0.026 \\
\hline $\mathrm{k}_{\mathrm{BC}}$ & $1 / \mathrm{d}$ & Fractional outflow rate from $\mathrm{B}$ to $\mathrm{C}$ & 0.134 \\
\hline$\alpha_{\mathrm{dmi}}$ & None & Scaling parameter between $(\mathrm{B}+\mathrm{C})$ and $\mathrm{DMI}$ value & 0.563 \\
\hline$\alpha_{\mathrm{my}}$ & None & Scaling parameter between $\mathrm{C}$ and $\mathrm{MY}$ value & 1.335 \\
\hline$\alpha_{\mathrm{mf}}$ & None & Scaling parameter between $\mathrm{C}$ and fat value & 0.419 \\
\hline$\alpha_{\mathrm{mp}}$ & None & Scaling parameter between $\mathrm{C}$ and protein value & 0.544 \\
\hline $\mathrm{DMI}_{0}$ & $\mathrm{~kg} / \mathrm{d}$ & Value of DMI at $\mathrm{T}_{\text {change }}$ of lactation & 2.53 \\
\hline $\mathrm{MY}_{0}$ & $\mathrm{~kg} / \mathrm{d}$ & Value of MY at $\mathrm{T}_{\text {change }}$ of lactation & 1.84 \\
\hline $\mathrm{Fat}_{0}$ & $\%$ & Value of fat at $T_{\text {change }}$ of lactation & 4.49 \\
\hline Protein $_{0}$ & $\%$ & Value of protein at $T_{\text {change }}$ of lactation & 4.15 \\
\hline $\mathrm{BW}_{0}$ & & Value of $\mathrm{BW}$ at $\mathrm{T}_{\text {change }}$ of lactation & 64.5 \\
\hline $\mathrm{E}_{\text {diet }}$ & $\mathrm{MJ} / \mathrm{kg}$ & Net energy of the diet & 6.12 \\
\hline
\end{tabular}

${ }^{1}$ See the text for further explanation and the Appendix for differential equations.

${ }^{2} \mathrm{MY}=$ milk yield; $\mathrm{T}_{\text {change }}=$ time of change, occurring when the estimated $\mathrm{MY}$ was at a minimum in the period 300 to 390 DIM.

are 2 key parameters used to characterize the global delay in energy transfer from feed to milk (Table 1). By controlling the discharge of compartment $\mathrm{A}$ into $\mathrm{B}, \mathrm{k}_{\mathrm{AB}}$ activates the rise in DMI (DMI is driven by $1-\mathrm{A}$ ). The mean residence time of $\mathrm{A}$ (defined by $1 / \mathrm{k}_{\mathrm{AB}}$ ) is the time needed to increase the quantity $1-\mathrm{A}$ from its initial value (0) to about 0.63 (Figure 5 ). In others words, $\mathrm{k}_{\mathrm{AB}}$ controls the rate of increase in DMI and, as a consequence, the rate of increase in energy input. By controlling the discharge of compartment B into C, $\mathrm{k}_{\mathrm{BC}}$ activates the changes in milk variables. Milk yield increase is driven by $\mathrm{C}$, whereas fat and protein content decreases are driven by $-\mathrm{C}$. The mean residence time in compartment $\mathrm{B}$ (defined by $1 / \mathrm{k}_{\mathrm{BC}}$ ) is the extra time to $1 / \mathrm{k}_{\mathrm{AB}}$, which is needed to increase the quantity $\mathrm{C}$ from its initial value (0) to about 0.63 (Figure 5). In others words, $\mathrm{k}_{\mathrm{BC}}$ controls the time lag between the rise in DMI and the changes in milk variables and, as a consequence, the time lag between the changes in feed energy input and milk energy output. Any change in the driven variables (DMI, MY, Fat, and Protein) result from the multiplication of the driving factors with 4 scaling parameters (Figure 4), the values of which were obtained by fitting to the average EL profile $\left(\alpha_{\text {dmi }}\right.$, $\alpha_{\mathrm{my}}, \alpha_{\mathrm{mf}}$, and $\alpha_{\mathrm{mp}}$ in Table 1). Initially (at $\mathrm{T}_{\text {change }}$ or d 0 of the EL profile), the relative quantity of A is 1 [i.e., $100 \%$, so that of $\mathrm{B}$ and $\mathrm{C}$ is zero (Figure 5)]. As a consequence, none of the variables (DMI, MY, Fat, and Protein) is influenced by the driving factors at $\mathrm{d} 0$, so their value only equals the initial estimates $\left(\mathrm{DMI}_{0}\right.$, $\mathrm{MY}_{0}, \mathrm{Fat}_{0}$, and Protein 0 ).

The simulated adjusted variables were then used for the calculation of EB (Figure 4), assuming that energy inputs $\left(E_{\text {in }}\right)$ result from DMI multiplied with the estimated net $\mathrm{E}_{\text {diet. }}$. Energy requirements $\left(\mathrm{E}_{\mathrm{req}}\right)$ for milk production and maintenance were defined according to the equations of Sauvant et al. (2007; Appendix). The resulting $\mathrm{EB}$ is equivalent to the net energy available for any change in BW, so this was used in the model to compute theoretical $\mathrm{BW}$ changes and thus the $\mathrm{BW}$ evolution during the onset of EL.

The number of parameters (11) estimated using the group average profile is relatively high, regarding the number of variables observed (5); thus, not surprisingly, the fit was globally good, as shown in Figure 3 (continuous lines) and quantified in Table 2 (2 first columns). Globally, the model was able to describe an average time profile of performance (mean $\mathrm{CD}=75 \%$ for the 5 variables observed), except for milk fat content and EB, where the model simulated a consistent tendency but failed to track some of the systematic variations that were observed around the general trend (Figure $3 \mathrm{~B}$ and $3 \mathrm{C}$ ). The internal consistency of the model, as estimated by $\mathrm{EB}$ and the resulting $\mathrm{BW}$, agreed with observations (Figure 3B), especially after $30 \mathrm{~d}$. As there was a relative lack of data and higher variability during the first $30 \mathrm{~d}$ of simulation, model outputs during this period require cautious consideration. Given this, the model seemed to correctly represent an average energy partitioning at the onset of EL and validated the hypothesis of a global delay in the transfer of energy from feed to milk at the onset of EL. This global delay (sum of $1 / \mathrm{k}_{\mathrm{AB}}$ and $1 / \mathrm{k}_{\mathrm{BC}}$ ) was of $45 \mathrm{~d}$ (Table 1 ). About $85 \%$ of it was related to the rate of increase in DMI (due to the mean residence time of $\mathrm{A}$ of about $38 \mathrm{~d}$ ), whereas the remaining $15 \%$ was related to the time lag between the increase in DMI and MY (due to the mean residence time of $\mathrm{B}$ of about $7 \mathrm{~d}$ ). After accounting for the maintenance requirements, the coefficient of partition between milk and body gains $\left(\mathbf{P}_{\text {milk }}\right)$ calculated from the model indicated that, on average a high proportion (75\%) of energy goes to milk during the first $90 \mathrm{~d}$ of EL. The $\mathrm{P}_{\text {milk }}$ increased from $67 \%$ at wk 1 of EL to $81 \%$ at wk 13 . 

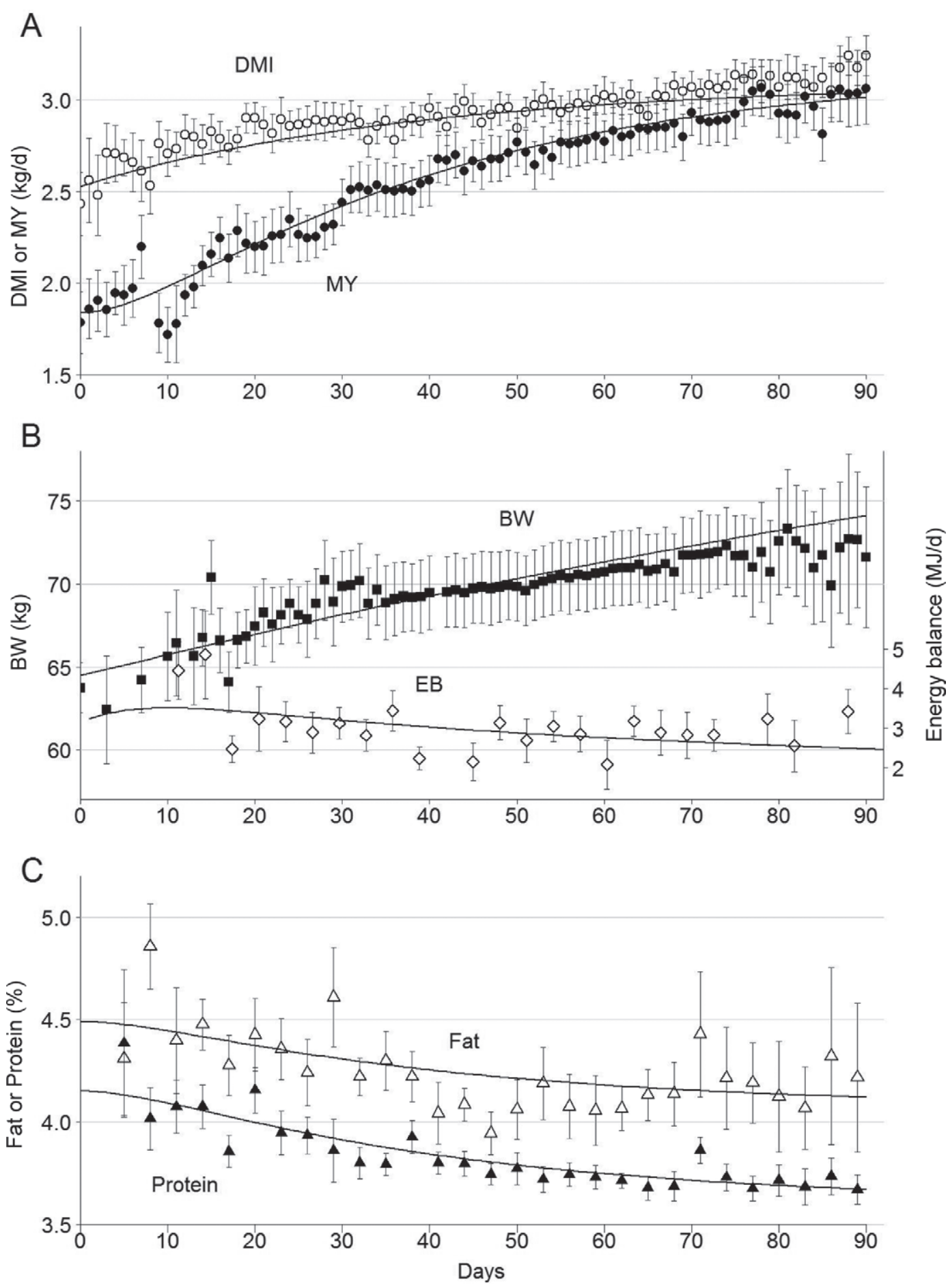

Figure 3. (A) The average intake (DMI; $\bigcirc)$, milk yield (MY; $\bullet),(B) B W(\boldsymbol{\square})$, energy balance (EB; $\diamond)$, and $(\mathrm{C})$ milk fat $(\Delta)$ and protein $(\boldsymbol{\Delta})$ contents relative to the onset of extended lactations in dairy goats (daily mean values $\pm \mathrm{SE}$ ). The continuous line represents the fitted model.

\section{Model Ability to Fit the Range of Individual Profiles}

Additional simulations were done to assess the ability of the model to fit a range of individual profiles at the onset of EL. For this, the observed performances of the 20 individuals during the onset of EL were used. Individual differences explained a high proportion of the total variability observed in the 5 variables: $70 \%$ for DMI, $58 \%$ for MY, $63 \%$ for fat, $52 \%$ for protein, $74 \%$ for $\mathrm{EB}$, and $94 \%$ for BW (data not reported). 


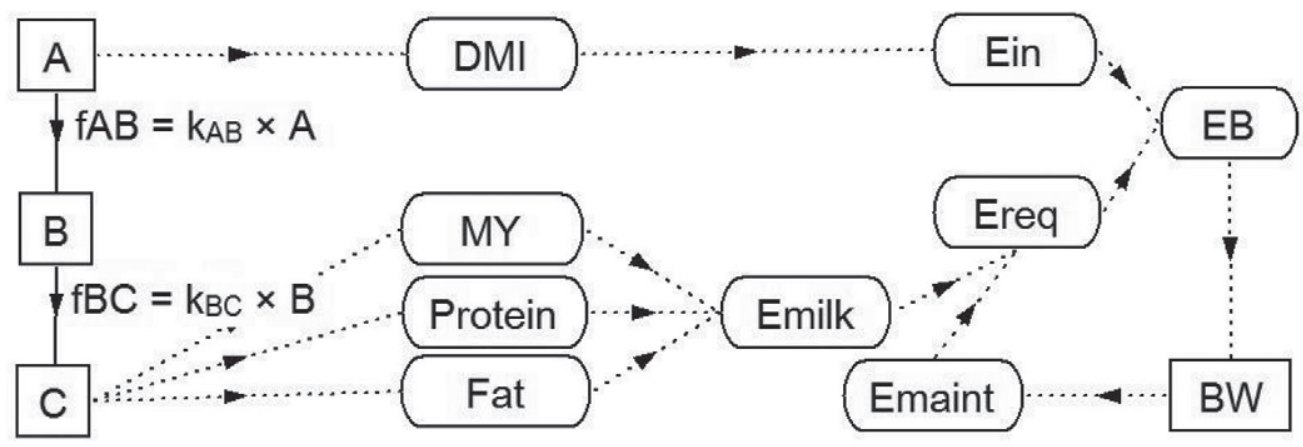

\begin{tabular}{|c|c|c|}
\hline Driving Factors: & Driven Variables: & Resulting EB and BW: \\
\hline $\begin{array}{l}d A / d t=-f A B \\
d B / d t=f A B-f B C \\
d C / d t=f B C\end{array}$ & $\begin{array}{l}\mathrm{DMI}=\mathrm{DMl}_{0}+(1-\mathrm{A}) \times \alpha_{\mathrm{dmi}} \\
\mathrm{MY}=\mathrm{MY} \mathrm{Y}_{0}+\mathrm{C} \times \alpha_{\mathrm{my}} \\
\text { Fat }=\text { Fato }-\mathrm{C} \times \alpha_{\mathrm{mf}} \\
\text { Protein = Protein }-\mathrm{C} \times \alpha_{\mathrm{mn}}\end{array}$ & $\begin{array}{l}E_{\text {in }}=E_{\text {diet }} \times D M l \\
E_{\text {req }}=E_{\text {milk }}+E_{\text {maint }} \\
E B=E_{\text {in }}-E_{\text {req }}\end{array}$ \\
\hline $\begin{array}{l}A(0)=1 \\
B(0)=C(0)=0\end{array}$ & Protein = Proteino - $c \times \alpha_{m p}$ & $\begin{array}{l}\mathrm{dBW} / \mathrm{dt}=\mathrm{EB} /(3.9 \times 7.12) \\
\mathrm{BW}(0)=\mathrm{BW}_{0}\end{array}$ \\
\hline
\end{tabular}

Figure 4. Diagram of the model showing the successive compartments of driving factors (A, B, and C) used to model the regulation of the variables DMI, milk yield (MY), and milk fat and protein content during the onset of extended lactation in dairy goats. Fluxes are represented by continuous arrows and are named using f followed by the names of the 2 affected compartments. Forrester's symbolism is used: boxes $=$ compartments; ovals = variables; solid arrows $=$ flux of matter, dotted arrows = flux of information. $\mathrm{E}_{\text {in }}=$ energy input; $\mathrm{EB}=$ energy balance; $\mathrm{E}_{\text {req }}=$ energy requirements; $\mathrm{E}_{\text {milk }}=$ energy for milk production; $\mathrm{E}_{\text {maint }}=$ energy for maintenance; $\mathrm{t}=$ days from the time of change $\left(\mathrm{T}_{\text {change }} ;\right.$ time of change, occurring when the estimated MY was at a minimum in the period 300 to 390 DIM). All other parameter definitions are presented in Table 1. Additional differential equations are presented in the Appendix.

Thus, the data set of individual observations seemed to be a good candidate to assess the model ability to fit a range of profiles at the onset of EL. The initial parameters $\left(\mathrm{DMI}_{0}, \mathrm{MY}_{0}, \mathrm{Fat}_{0}\right.$, Protein 0 , and $\left.\mathrm{BW}_{0}\right)$ were thus adjusted individually to simulate the individual profiles. The values of the 7 other parameters were kept from the calibration to the group average profile, assuming that the dynamic process was the same for all individuals after determining the vector of initial values (Table 1). The results are shown in Table 2 and Figure 6. Once the initial values of the estimated group average profile have been adjusted individually, a large improvement in the fit was obtained with BW observations, as the resulting RMSE was close $(+22 \%)$ to that obtained with the group average profile. For the other variables, much more time variation was observed and, consequently, the error improvements were not so good. In particular, it seems that the time variations from the different variables were aggregated in the calculated values of $\mathrm{EB}$, which can explain the high RMSE for this variable. The low $\mathrm{CD}_{\mathrm{RES}}(-8.2 \%)$ reported in Table 2 is illustrated in Figure 6. The model seemed to correctly explain the average differences in EB between individuals (white squares) but much less so the within-individual variations (gray points) around every average value. Nevertheless, the model described, on average, $44 \%$ (mean of the 5 first $\mathrm{CD}_{\mathrm{RES}}$ of the last column of Table 2) of the intraindividual variability observed in the 20 time profiles. Thus, merely adjusting the initial values and not the scaling parameters

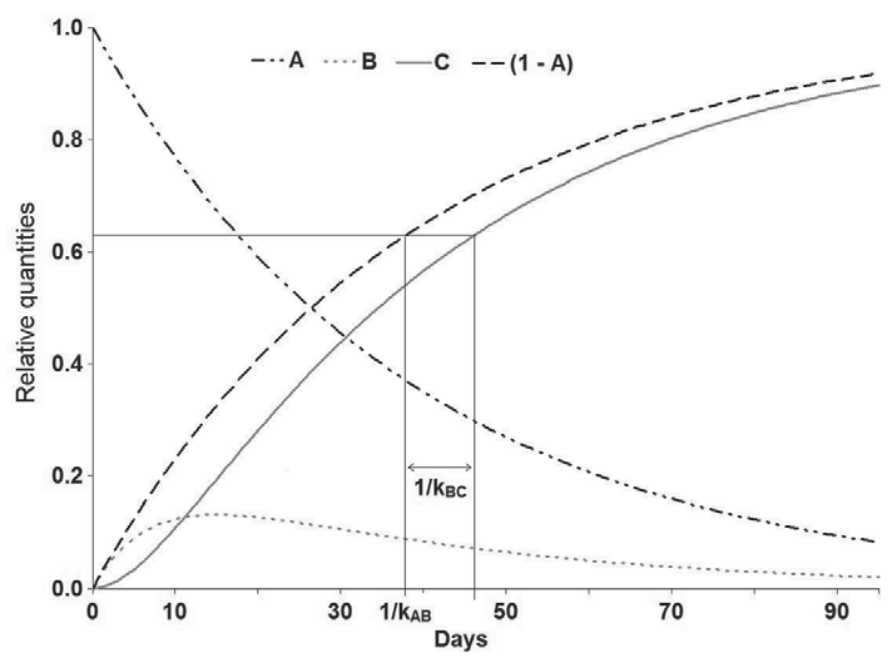

Figure 5. Relative quantities of the driving factors $\mathrm{A}, \mathrm{B}$, and $\mathrm{C}$ resulting from successive first-order reactions $\mathrm{A} \rightarrow \mathrm{B} \rightarrow \mathrm{C}$ and used to represent the regulation of DMI $(1-\mathrm{A})$ and milk yield (MY; C) during the onset of extended lactation in dairy goats. $1 / \mathrm{k}_{\mathrm{AB}}=$ mean residence time of $\mathrm{A}$, where $\mathrm{k}_{\mathrm{AB}}$ is the fractional outflow rate from $\mathrm{A}$ to $\mathrm{B} ; 1 / \mathrm{k}_{\mathrm{BC}}=$ mean residence time in compartment $\mathrm{B}$, where $\mathrm{k}_{\mathrm{BC}}$ is the fractional outflow rate from $\mathrm{B}$ to $\mathrm{C}$. 
Table 2. The root mean square errors (RMSE) and coefficients of determination (CD) of the model when fitted to the average profile data, and to the individual profiles data $(\mathrm{n}=20)$

\begin{tabular}{|c|c|c|c|c|}
\hline \multirow[b]{3}{*}{ Variable } & \multirow{2}{*}{\multicolumn{2}{|c|}{$\frac{\text { Average profile data set }}{\text { All parameters adjusted }^{1}}$}} & \multicolumn{2}{|c|}{ Individual profile data set $(\mathrm{n}=20)$} \\
\hline & & & \multicolumn{2}{|c|}{ Initial value $^{2}$} \\
\hline & RMSE & $\mathrm{CD}(\%)$ & RMSE & $\mathrm{CD}_{\mathrm{RES}}^{3}(\%)$ \\
\hline DMI (kg/d) & 0.065 & 84.4 & 0.196 & 20.7 \\
\hline MY $(\mathrm{kg} / \mathrm{d})$ & 0.078 & 95.6 & 0.237 & 67.1 \\
\hline Fat $(\%)$ & 0.150 & 37.0 & 0.342 & 10.9 \\
\hline Protein $(\%)$ & 0.082 & 76.0 & 0.141 & 48.6 \\
\hline BW (kg) & 1.064 & 75.7 & 1.217 & 70.2 \\
\hline $\mathrm{EB}(\mathrm{MJ} / \mathrm{d})$ & 0.575 & 15.6 & 1.345 & -8.2 \\
\hline
\end{tabular}

${ }^{1}$ All the parameters used in the model were those derived from the group average profile (Table 1).

${ }^{2}$ For initial values, only the initial parameters $\left(\mathrm{DMI}_{0}, \mathrm{MY}_{0}, \mathrm{Fat}_{0}\right.$, Protein $_{0}$, and $\left.\mathrm{BW}_{0}\right)$ were adjusted individually; the values of the other parameters are those of the group average profile (Table 1 ).

${ }^{3}$ Coefficient of determination calculated with the residual sum of squares of the observed data for each variable (see Materials and Methods).

seemed to allow a substantial integration of individual variations. No systematic bias was obvious for the 6 variables (Figure 6).

To explore further the individual relationships between performances during EL, PC analysis was performed on the initial parameters estimated $\left(\mathrm{DMI}_{0}\right.$, $\mathrm{MY}_{0}$, $\mathrm{Fat}_{0}$, Protein ${ }_{0}$, and $\mathrm{BW}_{0}$ ) and the average EB $\left(\mathrm{EB}_{90}\right)$ and $\mathrm{ADG}\left(\mathrm{ADG}_{90}\right)$ calculated over the first $90 \mathrm{~d}$ of EL (Figure 7). The 2 first axes of the PC accounted for respectively 40.2 and $30.2 \%$ of the total variation (Figure 7A). Principal component 1 discriminated low from high values of $\mathrm{EB}_{90}(\mathrm{r}=0.97)$ and $\mathrm{ADG}_{90}(\mathrm{r}=$ 0.97 ), whereas $\mathrm{PC} 2$ indicated that, independently from $\mathrm{PC} 1$, high levels of $\mathrm{MY}_{0}(\mathrm{r}=0.85)$ and $\mathrm{BW}_{0}(\mathrm{r}=0.53)$ were associated with low milk protein $(\mathrm{r}=-0.70)$ and fat $(\mathrm{r}=-0.43)$ contents at $\mathrm{T}_{\text {change }}$. The $\mathrm{DMI}_{0}$ was positively correlated $(\mathrm{r}=0.64)$ as much with $\mathrm{PC} 1$ as with $\mathrm{PC} 2$. The interpretation of these results was helped by the projection onto the plot of non-weighted supplementary variables, reflecting the average performances measured over 300 DIM in period $\mathrm{n}-1\left(\mathrm{MY}_{\mathrm{n}-1}, \mathrm{BW}_{\mathrm{n}-1}\right.$, and $\left.\mathrm{BCS}_{\mathrm{n}-1}\right)$, as well the age and litter weight at last kidding. The BCS $\left(\mathrm{BCS}_{90}\right)$ and milk efficiency $\left(\mathrm{EFF}_{90}\right)$ observed on average over the first $90 \mathrm{~d}$ of EL were also used, as these variables were not simulated in the model. These 2 last variables were opposed on PC1, so observations concurred with model predictions on the interpretation of $\mathrm{PC} 1$ as being an axis that distinguished the partition of energy intake toward body reserves (right side) or milk (left side) during the onset of EL. Subsequently, the variations in $\mathrm{BCS}_{n-1}$ and $\mathrm{BW}_{\mathrm{n}-1}$ were found to be highly correlated with those estimated at $\mathrm{T}_{\text {change, }}$, whereas MY seemed less correlated across time.

The score plot (Figure 7B) shows the 20 individuals clustered in 4 main groups according to their score on
PC1 and PC2. During period $\mathrm{n}-1$, group $1(\mathrm{n}=7$, including the average profile) and group $2(\mathrm{n}=4)$ were respectively the groups with the highest and lowest values of BW, BCS, and MY. Thus, these 2 groups seemed to distinguish high (top right) from low (bottom left) potential for NL. Over the first $90 \mathrm{~d}$ of EL, group 3 $(\mathrm{n}=4)$ had the highest average MY $(3.38 \pm 0.111$ $\mathrm{kg} / \mathrm{d}$ ) compared with the 3 others groups (all below $2.5 \mathrm{~kg} / \mathrm{d}$ ), In contrast, during the same period, group $4(\mathrm{n}=4)$ showed the lowest values for both efficiency and MY. Thus, these observations seemed to indicate a preferential energy partition toward milk (top left) or toward body tissue gain (bottom right) at the onset of EL. This was confirmed with the average partition coefficients $\left(\mathrm{P}_{\text {milk }}\right)$ calculated with the model over the onset of EL, as group 3 had the highest value (81.5\%), whereas group 4 had the lowest $(58.2 \%)$. Moreover, individuals with the lowest performances during NL (group 2) tended to partition their energy similarly to group 3 during EL $\left(\mathrm{P}_{\text {milk }}=80.3 \%\right)$. This partition to milk was even greater than individuals with the highest performances during NL (group 1; $\mathrm{P}_{\text {milk }}=72.3 \%$ ).

\section{DISCUSSION}

This study characterized the time profiles of performance of dairy goats undergoing EL by comparing their milk production and BW with those of goats having 2 successive NL and by modeling the changes in milk production, BW, and DMI at the onset of EL. To our knowledge, this is the first attempt in dairy goats to describe the relationships between concurrent energy functions during EL, because previous investigations have mainly focused on the lactation curve or on milk production (Linzell, 1973; Chastin et al., 2001; Salama et al., 2005). Beyond showing that EL goats 

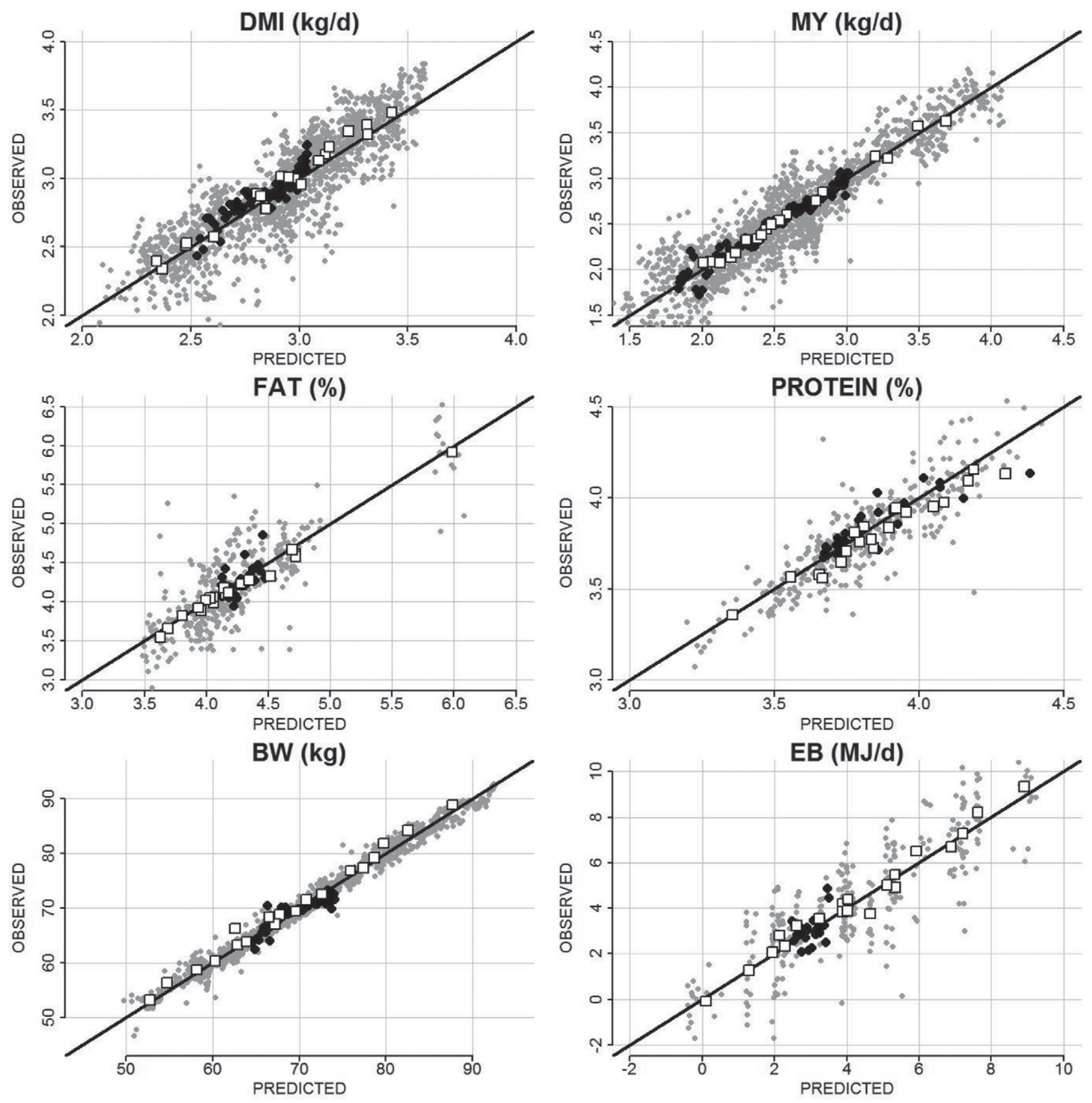

Figure 6. Observed and predicted values of the state variables milk yield (MY), DMI, fat and protein contents in milk, and BW for the group average profile (black) and the 20 individual profiles (gray) at the onset of extended lactation. The average values of the 20 individual profiles are also shown $(\square)$. EB = energy balance.

could produce as much milk as NL goats over $2 \mathrm{yr}$, this study demonstrates that EL efficiency depends both on an increase in resource acquisition and on the potential of goats to partition energy from the diet toward milk production instead of to body tissue gain.
Comparing the evolution of MY, fat and protein content, and SCC during EL with those of 2 successive NL suggests that, in terms of milk production, EL is more analogous with a new lactation (i.e., an increase to "peak phase" followed by a "persistency phase"; Gipson 
and Grossman, 1989), rather than with a simple extension of NL. Extended-lactation goats showed higher persistency than NL pregnant goats due to the negative effect of pregnancy on MY, which was detected from wk 7 after conception. This was close to the results reported by Knight and Wilde (1987; 8 wk) and Salama et al. (2005; 10 wk). Although the persistency phase was about 1 mo longer for EL goats than NL goats, the onset of EL was primarily characterized by the initiation of a second peak phase lower but longer than the normal peak phase (Figure 1A). During this phase, a dilution effect can lead to higher milk fat and protein content in milk of EL compared with NL (Salama et al., 2005). However, our study does not support this for milk fat, as no significant difference existed between EL and NL (Figure 2).

In terms of BW, it is clear from the observed profiles that EL goats differ substantially from NL goats. The most striking difference was the rapid and very high BW increase $(+9.3 \mathrm{~kg}$, with an ADG of $60.4 \mathrm{~g} / \mathrm{d})$ that was observed concurrently with the increase in MY (Figure 1B). These BW gains appear exceptionally high compared with references to goats regaining body reserves during an NL (between wk 7 and 27) being twice that of goats in parity 2 and 4 times that of goats in parity 3 or more (Sauvant et al., 2012). Body weight variations could also be due to variations in gut fill, notably because EL goats were increasing their DMI when the rise in BW was observed (Figure 3). However, the calculated values of EB were largely positive during the onset of EL $(+3.03 \pm 0.13 \mathrm{MJ} / \mathrm{d}$ for the average profile) and tended to progressively decrease consistently with the asymptotic trend in BW. Thus, this seems to indicate that the observed increase in BW of EL goats was mainly due to body reserve accumulation. Conversely, EL goats showed almost no increase in $\mathrm{BW}$ as MY decreased, neither from wk 37 to $\mathrm{T}_{\text {change }}$ in period n-1 nor from wk 23 to 39 (wk 6 of pregnancy) in period n. Furthermore, EL goats reached a BW similar to NL goats by the end of pregnancy in period n. Collectively, the BW and MY profiles suggest that a key effect of EL on dairy goat performance is to disrupt the phase opposition between MY and BW dynamics, which usually takes place during NL.

The results from modeling the onset of EL do not support the proposition that the rise in MY drives the increase in resource acquisition, as it is generally assumed at the onset of an NL. In contrast, it suggests that DMI is the driving force responsible for the increase in both MY and BW. In this experiment, the feeding conditions were constant: the quantities of DM offered were nonlimiting and the diet was of high energy value; thus, it can be considered that the increase in DMI did not result from a feeding effect. Another
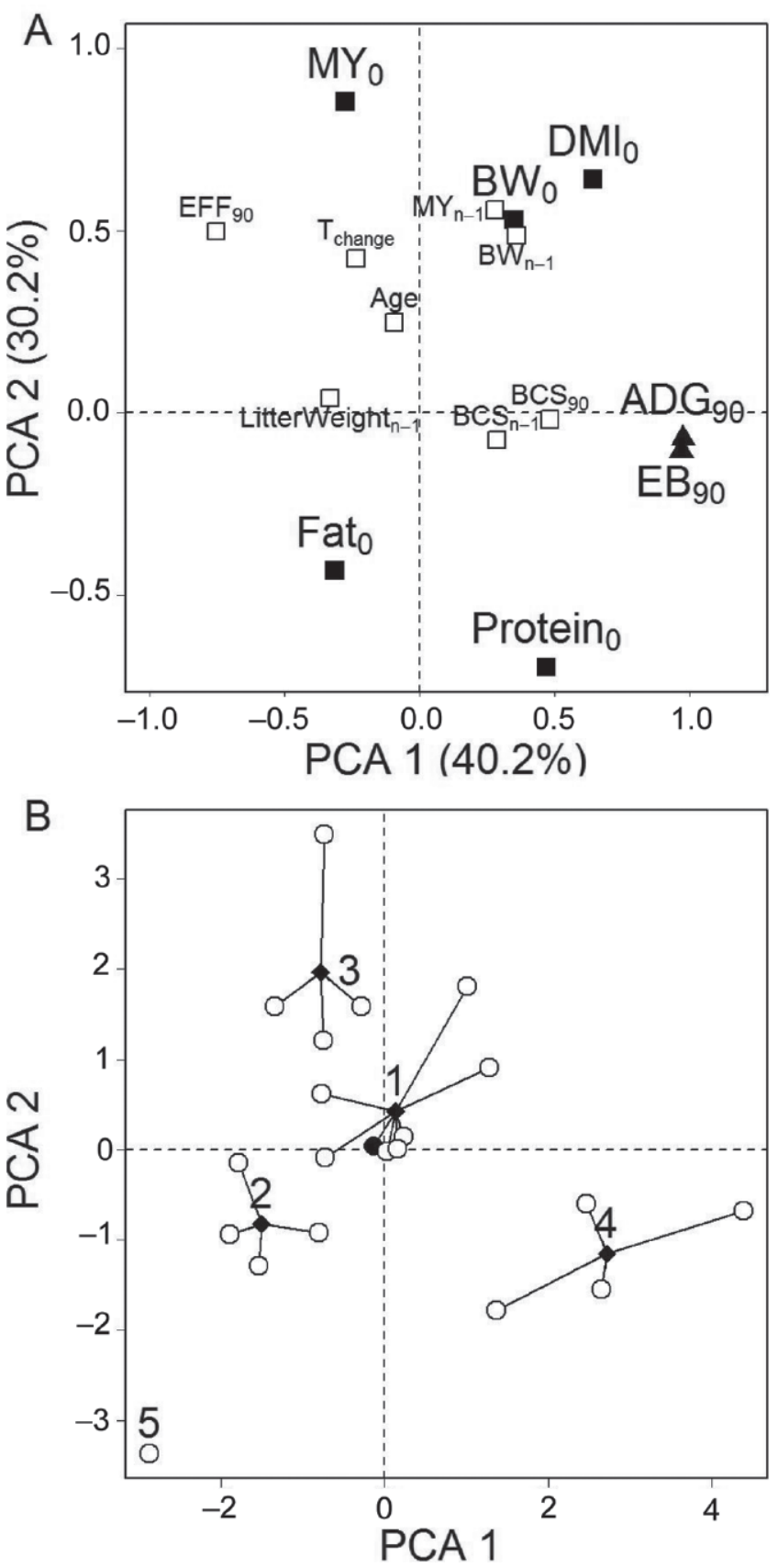

Figure 7. (A) Plot of the first 2 principal components of a principal components analysis (PCA) performed on the estimated values (ם) of initial parameters $\left[\mathrm{DMI}_{0}, \mathrm{MY}_{0}, \mathrm{Fat}_{0}\right.$, Protein $_{0}$, and $\mathrm{BW}_{0}$, representing the values of DMI, milk yield (MY), fat, protein, and BW at time of change ( $\mathrm{T}_{\text {change }}$; occurring when the estimated MY was at a minimum in the period 300 to 390 DIM) of lactation, respectively] and on the predicted values $(\mathbf{\Lambda})$ of average energy balance $\left(\mathrm{EB}_{90}\right)$ and ADG $\left(\mathrm{ADG}_{90}\right)$ over the first $90 \mathrm{~d}$ of EL for the 20 individual profiles. Nonweighted supplementary variables $(\square)$ were added to the plot to aid interpretation; $\mathrm{EFF}=$ milk efficiency. Subscripts $\mathrm{n}-1$ and 90 indicate respectively an average daily value over the first 300 DIM and the first $90 \mathrm{~d}$ of extended lactation (EL). See text for explanation. (B) Score plot of the 20 individuals $(\bigcirc)$ and the non-weighted average profile $(\bullet)$. The 5 different clusters obtained after hierarchical clustering on principal components were used to project their respective barycenter $(\diamond)$, as identified with their numbers from 1 to 5 . 
possible reason for observing an increase in DMI during the reproductive cycle can be increasing requirements for covering particular physiological functions (e.g., lactation and gestation). The present observations do not support this hypothesis because MY appeared to be delayed compared with DMI and EB remained positive during the entire period. In the model, a time lag of about $7 \mathrm{~d}$ (equal to $1 / \mathrm{k}_{\mathrm{AB}}$ ) was found between the increase in DMI and the increase in MY. Consequently, in this study, DMI seemed to be the driving force of the changes at the onset of EL.

However, a critical assumption reflected in the model structure was that the BW dynamic is a consequence of DMI and milk production rather than a possible driving force at the onset of EL. The main reason for that assumption was to allow the use of body energy changes as a means to check the internal consistency between the parameters related to the dynamics of the different measured items. It is well known that body energy change can be an important driver during certain periods of the reproductive cycle when females regain body reserves (Friggens et al., 2004). However, our comparative approach (Figure 2) suggests that before $\mathrm{T}_{\text {change }}$, the most important gains in $\mathrm{BW}$ were related to the pregnancy of an NL, whereas BW of EL goats increased noticeably only after $\mathrm{T}_{\text {change. }}$ This is consistent with previous studies in dairy cows that showed a pregnancy effect on body reserves storage (Friggens et al., 2010). In our experiment, the relative lack of data on BW and DMI for the first 2 wk at the onset of EL prevents any clear opinion about the driving force at the onset of EL in goats. Whereas it is not possible to exclude the possibility of BW being a significant driver, the observed data from the end of period $n-1$ together with the coherent simulation results from period $n$ do not provide any contradiction to the suggestion of DMI being the driving force.

The model presented here operates at a high level of description; thus, it does not attempt to describe the mechanisms that activate the increase in DMI but merely opens questions on its origin. Season has been put forward as a possible trigger for resource acquisition and the effect of photoperiod on MY and DMI has been explored in seasonal breeders such as sheep (Bocquier et al., 1997) and goats (Garcia-Hernandez et al., 2007). It is generally reported that an increasing photoperiod stimulates first MY and then DMI during an NL, whereas our study showed that DMI increased first at the onset of EL. Furthermore, our study agrees with other studies on EL where $\mathrm{T}_{\text {change }}$ occurred in decreasing daylight, at the beginning of the winter in Spain (Salama et al., 2005) or in France (Chastin et al., 2001). Thus, it can be assumed that the activation of $\mathrm{T}_{\text {change }}$ is not related to the photoperiodic effect reported during NL. In Chastin et al. (2001), $\mathrm{T}_{\text {change }}$ occurred at the same month for goats that kidded either in December or in February in period $\mathrm{n}-1$; thus, $\mathrm{T}_{\text {change }}$ might be primarily triggered by clues as to the time of the year. However, Linzell (1973) observed that MY of EL goats varied cyclically even with a constant long day photoperiod but their cycle was shortened by about 5 wk compared with natural light changes. Therefore, $\mathrm{T}_{\text {change }}$ might reflect an innate seasonal adaptation of goats, which is nevertheless subject to some effect from the rate of change in daylight.

Different physiological mechanisms under seasonal control exist and can underlie the changes of relationships between DMI, MY, and BW (Rhind et al., 2002; Lincoln et al., 2003). If DMI increases first during an anabolic growth phase (and not as a consequence of a greater energy requirement from the mammary gland), this can be the result of a neural mechanism that controls a long-term cycle in food intake and BW (Lincoln et al., 2001). Even for farm animals, such cycles can persist under constant conditions of temperature and light, as was the case for the seasonal cycles in MY observed by Linzell (1973) during EL. In the present study, these long-term cycles in MY during EL seem to be driven by cycles in intake. However, the onset of EL ( $\left.\mathrm{T}_{\text {change }}\right)$ occurred during the short days, at the beginning of winter, whereas the usually reported pattern of the cycle in non-reproductive animals is an increase in intake and BW during long days, from spring to autumn, when food is usually abundant under natural conditions. The evidence from the present study suggests an additional seasonally cued driver linked to the reproductive cycle. Linzell (1973) observed seasonal variations in udder volume along with those of MY during EL, even when goats were ovariectomized. This suggested anticipatory mammary growth, occurring independently from the gonadotropic axis. Although no clear evidence exists to identify the endocrine mechanisms involved, it can be speculated that the disruption of the phase opposition between MY and BW dynamics observed during EL is the consequence of an anticipatory anabolism, interacting with the lactotroph axis. Clearly, this issue warrants further investigation with the appropriated measures at a physiological level.

Adjusting only the initial parameters values of the model allowed a substantial incorporation of individual differences. This suggests that the performances over the first $90 \mathrm{~d}$ of EL are largely predetermined by the animal state at $\mathrm{T}_{\text {change }}$ (as described with $\mathrm{DMI}_{0}, \mathrm{MY}_{0}$, $\mathrm{Fat}_{0}$, Protein $_{0}$, and $\mathrm{BW}_{0}$ ). Potentially, this leads to at least 2 interesting implications. First, a predetermined trajectory can allow better prediction of goat performance at the onset of EL and thus allow the appropriate feeding strategy to be used. Second, this suggests 
that the potential of goats for EL can be estimated from $\mathrm{T}_{\text {change }}$ and used to develop new criteria for the improvement of culling strategies. This relies on the assumption that the first $90 \mathrm{~d}$ of EL are representative of a potential for EL. Fully exploring this assumption is beyond the scope of the present study and would require much more data than was available in the present study. However, under this assumption, our analysis suggests no clear relationship between the potential for NL (as estimated by $\mathrm{MY}_{\mathrm{n}-1}$ ) and the potential for EL. In our analysis, it is suggested that the potential for EL is positively associated with lactation persistency (in period $n-1$ ), as the more productive goats during the onset of EL (e.g., group 3) had both a high DMI and $\mathrm{MY}$ at $\mathrm{T}_{\text {change }}$. Goats with high milk production in period $_{n-1}$ that did not fulfill these conditions (e.g., group 1) tended to partition a considerable amount of energy toward body reserves instead of milk. However, when considering efficiency rather than MY during the onset of EL, some goats (e.g., group 2) can be good performers during EL despite relatively low production and persistency during period $\mathrm{n}_{\mathrm{n}-1}$. From this view, the potential for EL could depend more on the goats' capacity to partition energy from the diet toward milk production instead of to body tissue gain rather than on absolute levels of DMI and MY.

Although in the present study we could only model the onset of EL (i.e., the first $90 \mathrm{~d}$ ), it would be of interest to extend this approach to provide information about peak yield and persistency of EL. This is an issue that is usually explored with lactation curve models (Gipson and Grossman, 1989; Dematawewa et al., 2007; Steri et al., 2012). However, even if models of NL curves have been fitted successfully to monotonically decreasing EL in dairy cows, they will probably not be flexible enough to accommodate the characteristic fluctuations depicted in the EL profile in dairy goats and a specific function may need to be developed. With the present model, no attempt was made to represent the transition between the persistency phase of NL and the onset of EL. Even if the compartmental structure provides an elegant way to describe the regulation of performances at the onset of EL with a limited number of state variables, it cannot accommodate the disruption of the phase opposition between MY and BW dynamics, which has been suggested by the comparative approach. Complete nutritional models based on the same principle of a compartmental regulating structure are able to represent complex dynamics during NL (Puillet et al., 2008; Martin and Sauvant, 2010); thus, they can be adequate candidates for incorporating the predetermined trajectory of EL, which has been suggested here.

\section{CONCLUSIONS}

The unified characterization of milk production and BW evolution for dairy goats undergoing EL provided evidence that a key effect of EL is to disrupt the phase opposition between MY and BW dynamics, which usually takes place during NL. This effect appears to be primarily driven at the onset of EL by a predetermined increase in resource acquisition, and is then characterized by a delayed transfer of energy from feed to milk. The individual variability observed in the relationships between milk production, liveweight, and intake at the onset of EL suggested that suitability of goats for EL is mostly based on a tendency for partitioning energy toward milk production instead of to body tissue gain during the onset of EL and possibly on a high NL persistency.

\section{REFERENCES}

Baumont, R., J. P. Dulphy, D. Sauvant, G. Tran, F. Meschy, J. Aufrère, J. L. Peyraud, and P. Champciaux. 2007. Les tables de la valeur des aliments. Pages 185-290 in Alimentation des bovins, ovins et caprins. Besoins des animaux - Valeurs des aliments. Quae ed. INRA, Paris, France.

Bocquier, F., F. Ligios, G. Molle, and S. Casu. 1997. Effect of photoperiod on milk yield, milk composition and voluntary food intake in lactating dairy ewes. Ann. Zootech. 46:427-438.

Butler, S. T., L. Shalloo, and J. J. Murphy. 2010. Extended lactations in a seasonal-calving pastoral system of production to modulate the effects of reproductive failure. J. Dairy Sci. 93:1283-1295.

Chastin, P., J. Martin, F. Monod, and E. Manfredi. 2001. Extended lactations at Moissac Goat Station (France). Page 271 in Proc. 8th meeting "Rencontres autour des recherches sur les ruminants." INRA and Institut de l'Elevage, Paris, France.

Dematawewa, C. M. B., R. E. Pearson, and P. M. VanRaden. 2007. Modeling extended lactations of Holsteins. J. Dairy Sci. 90:39243936 .

Desnoyers, M., S. Giger-Reverdin, C. Duvaux-Ponter, and D. Sauvant. 2009. Modeling of off-feed periods caused by subacute acidosis in intensive lactating ruminants: Application to goats. J. Dairy Sci. 92:3894-3906.

Friggens, N. C., C. Disenhaus, and H. V. Petit. 2010. Nutritional sub-fertility in the dairy cow: Towards improved reproductive management through a better biological understanding. Animal 4:1197-1213.

Friggens, N. C., K. L. Ingvartsen, and G. C. Emmans. 2004. Prediction of body lipid change in pregnancy and lactation. J. Dairy Sci. $87: 988-1000$.

Garcia-Hernandez, R., G. Newton, S. Horner, and L. C. Nuti. 2007. Effect of photoperiod on milk yield and quality, and reproduction in dairy goats. Livest. Sci. 110:214-220.

Gipson, T. A., and M. Grossman. 1989. Diphasic analysis of lactation curves in dairy goats. J. Dairy Sci. 72:1035-1044.

Grainger, C., M. J. Auldist, G. O'Brien, K. L. Macmillan, and C. Culley. 2009. Effect of type of diet and energy intake on milk production of Holstein-Friesian cows with extended lactations. J. Dairy Sci. 92:1479-1492.

Knight, C. H., and C. J. Wilde. 1987. Mammary growth during lactation: Implications for increasing milk yield. J. Dairy Sci. 70:19912000.

Kolver, E. S., J. R. Roche, C. R. Burke, J. K. Kay, and P. W. Aspin. 2007. Extending lactation in pasture-based dairy cows: I. Genotype and diet effect on milk and reproduction. J. Dairy Sci. 90:5518-5530. 
Lincoln, G. A., H. Andersson, and A. Loudon. 2003. Clock genes in calendar cells as the basis of annual timekeeping in mammals: A unifying hypothesis. J. Endocrinol. 179:1-13.

Lincoln, G. A., S. M. Rhind, S. Pompolo, and I. J. Clarke. 2001. Hypothalamic control of photoperiod-induced cycles in food intake, body weight, and metabolic hormones in rams. Am. J. Physiol. Regul. Integr. Comp. Physiol. 281:R76-R90.

Linzell, J. L. 1973. Innate seasonal oscillations in the rate of milk secretion in goats. J. Physiol. 230:225-233.

Martin, O., and D. Sauvant. 2010. A teleonomic model describing performance (body, milk and intake) during growth and over repeated reproductive cycles throughout the lifespan of dairy cattle. 1. Trajectories of life function priorities and genetic scaling. Animal 4:2030-2047.

Puillet, L., O. Martin, M. Tichit, and D. Sauvant. 2008. Simple representation of physiological regulations in a model of lactating female: Application to the dairy goat. Animal 2:235-246.

R Development Core Team. 2012. R: A language and environment for statistical computing. R Foundation for Statistical Computing, Vienna, Austria. Accessed Jun. 2012. http://www.r-project.org.

Rhind, S. M., Z. A. Archer, and C. L. Adam. 2002. Seasonality of food intake in ruminants: Recent developments in understanding. Nutr. Res. Rev. 15:43-65.

Rotz, C. A., D. L. Zartman, and K. L. Crandall. 2005. Economic and environmental feasibility of a perennial cow dairy farm. J. Dairy Sci. 88:3009-3019.

Salama, A. A. K., G. Caja, X. Such, R. Casals, and E. Albanell. 2005. Effect of pregnancy and extended lactation on milk production in dairy goats milked once daily. J. Dairy Sci. 88:3894-3904.

Sauvant, D. 1994. Modelling homeostatic and homeorhetic regulations in lactating animals. Livest. Prod. Sci. 39:105-113.

Sauvant, D., S. Giger-Reverdin, and F. Meschy. 2007. Alimentation des caprins. Pages 137-148 in Alimentation des bovins, ovins et caprins. Besoins des animaux-Valeurs des aliments. Quae ed. INRA, Paris, France.

Sauvant, D., F. Meschy, L. Puillet, and P. Schmidely. 2012. Actualisation des recommandations alimentaires pour les chèvres laitières. Prod. Anim. 25:259-276.

Steri, R., C. Dimauro, F. Canavesi, E. L. Nicolazzi, and N. P. P. Macciotta. 2012. Analysis of lactation shapes in extended lactations. Animal 6:1572-1582.

\section{APPENDIX}

\section{Model Equations}

Differential equations are presented below and parameter values and definitions are given in Table 1. The INRA system is used to calculate energy balance, so for all physiological functions, the same efficiency is assumed to convert ME to net energy.

\section{Compartments of Dimensionless Matter: A, B, and C}

$$
\begin{gathered}
\mathrm{dA} / \mathrm{dt}=-\mathrm{fAB} ; \\
\mathrm{dB} / \mathrm{dt}=\mathrm{fAB}-\mathrm{fBC} ; \\
\mathrm{dC} / \mathrm{dt}=\mathrm{fBC} ; \\
\mathrm{fAB}=\mathrm{k}_{\mathrm{AB}} \times \mathrm{A} ;
\end{gathered}
$$

$$
\begin{gathered}
\mathrm{fBC}=\mathrm{k}_{\mathrm{BC}} \times \mathrm{B} ; \\
\mathrm{A}(0)=1 ; \\
\mathrm{B}(0)=0 ; \\
\mathrm{C}(0)=0,
\end{gathered}
$$

where $t=$ days from the time of change $\left(\mathrm{T}_{\text {change }}\right.$; time of change, occurring when the estimated MY was at a minimum in the period 300 to 390 DIM) and $\mathrm{f}=$ flux, which is followed by the names of the 2 affected compartments.

\section{Variables Driven by $A, B$, and $C$}

$$
\begin{gathered}
\mathrm{DMI}=\mathrm{DMI}_{0}+(1-\mathrm{A}) \times \alpha_{\mathrm{dmi}} ; \\
\mathrm{MY}=\mathrm{MY}_{0}+\mathrm{C} \times \alpha_{\mathrm{my}} ; \\
\text { Fat }=\mathrm{Fat}_{0}-\mathrm{C} \times \alpha_{\mathrm{mf}} ; \\
\text { Protein }=\text { Protein }_{0}-\mathrm{C} \times \alpha_{\mathrm{mp}} .
\end{gathered}
$$

\section{Variables of the EB Calculation (MJ/d)}

$$
\begin{gathered}
\mathrm{E}_{\text {milk }}=\{\mathrm{MY} \times[0.4+0.055 \times(\text { fat }-3.5) \\
+0.033 \times(\text { protein }-3.1)]\} \times 7.12 ; \\
\mathrm{E}_{\text {maint }}=[0.79+0.01 \times(\mathrm{BW}-60)] \times 7.12 ; \\
\mathrm{E}_{\text {req }}=\mathrm{E}_{\text {milk }}+\mathrm{E}_{\text {maint }} ; \\
\mathrm{E}_{\text {in }}=\mathrm{E}_{\text {diet }} \times \mathrm{DMI} ; \\
\mathrm{EB}=\mathrm{E}_{\text {in }}-\mathrm{E}_{\text {req }} ; \\
\mathrm{P}_{\text {milk }}=\mathrm{E}_{\text {milk }} /\left(\mathrm{E}_{\text {in }}-\mathrm{E}_{\text {maint }}\right)
\end{gathered}
$$

where $\mathrm{E}_{\text {milk }}=$ energy for milk production, $\mathrm{E}_{\text {maint }}=$ energy for maintenance, $\mathrm{E}_{\mathrm{req}}=$ energy requirements, and $\mathrm{E}_{\text {in }}=$ energy input.

\section{BW Estimation from EB}

$$
\mathrm{dBW} / \mathrm{dt}=\mathrm{EB} /(3.9 \times 7.12) ;
$$$$
\mathrm{BW}(0)=\mathrm{BW}_{0} \text {. }
$$ 